\title{
UTJECAJ IZGRADNJE OBALNOG ZIDA NA DINAMIKU VALOVANJA ISPRED POSTOJEĆE PRIRODNE OBALE
}

\author{
SEAWALL CONSTRUCTION IMPACT ON WAVE \\ DYNAMICS OF NATURAL COAST
}

\author{
Andrija Grahovac*, Nino Krvavica*, Igor Ružić*
}

\begin{abstract}
Sažetak
U ovom radu opisan je utjecaj izgradnje obalnog zida na postojećoj prirodnoj stjenovitoj obali na dinamiku valovanja ispred obale, na primjeru projektiranja plaže Kostanj u Rijeci. Analize postojećeg i projektiranog stanja valovanja provedene su korištenjem numeričkog modela valovanja Simulating Waves Nearshore (SWAN) uz primjenu autorskih algoritama neophodnih za prikaz rezultata numeričkih simulacija. Predviđa se proširenje postojeće plaže prema zapadnom dijelu uvale nasipavanjem prirodne obale te izgradnjom armirano-betonskih zidova prema moru. Zbog izgradnje obalnih zidova doći će do povećanja koeficijenta refleksije valova $u$ odnosu na postojeću stjenovitu obalu. Ispred projektiranog zida, značajne visine valova juga 50 godišnjeg povratnog perioda povećat će se sa 2,20 na 2,50 m. U radu su opisane konstrukcijske metode umanjenja nepovoljnog učinka izgradnje obalnog zida na postojećoj stjenovitoj obali. Kao primjer opisano je i simulirano djelovanje zaštitnog podmorskog praga na polje valovanja ispred obalnog zida. Izgradnjom zaštitnog podmorskog praga s dubinom uronjenosti krune -2,0 m n.m. simulirane značajne visine valova juga 50 godišnjeg povratnog perioda su $1,90 \mathrm{~m}$ ispred projektiranog obalnog zida.
\end{abstract}

Ključne riječi: zid, refleksija valova, numeričke simulacije valovanja, podmorski prag

\begin{abstract}
This paper describes the impact of a sea wall on an existing rocky coastline wave dynamic, on the example of the Kostanj beach in Rijeka. Existing and designed significant waves heights were analysed by a numerical wave model Simulating Wave
\end{abstract}

\footnotetext{
${ }^{*}$ Sveučilište u Rijeci, Građevinski fakultet, Radmile Matejčić 3, 51000 Rijeka E-mail: andrija.grahovac@student.uniri.hr, \{nino.krvavica,iruzic\}@gradri.uniri.hr
} 
earshore (SWAN), with the application of the original algorithms for illustrating the numerical simulation results. The existing beach design proposes an extension of the existing beach on the western part of the bay by building coastal walls along thenatural coastline. This will increase the wave reflection coefficient relative to the existing coastline. In front of the designed wall a 50-year return period SSE significant wave height will increase from 2,20 to 2,50 m. This paper describes the construction methods for reducing the negative effect of construction of a coastal wall on an existing rocky shoreline. As described and simulated, the submerged breakwater with crown position at $2 \mathrm{~m}$ a.s.l. depth, reduces 50 years return period SSE significant wave height from 2,50 to $1,90 \mathrm{~m}$.

Key words: wall, wave reflection, numerical wave simulation, submerged breakwater

\section{Uvod}

U ovom radu opisan je utjecaj izgradnje obalnog zida plaže i zaštitnog podmorskog praga na prirodnoj stjenovitoj obali na dinamiku valovanja ispred same obale na primjeru projektiranja plaže Kostanj u Rijeci. Analiziran je utjecaj više varijanti podmorskog praga ispred projektirane obale na dinamiku valovanja, a s ciljem umanjenja nepovoljnih učinaka izgradnje obalnog zida.

Analize postojećeg i projektiranog stanja valovanja provedene su korištenjem numeričkog modela valovanja Simulating Waves Nearshore (SWAN) [1] uz primjenu autorskih algoritama neophodnih za prikaz i interpretaciju rezultata numeričkih simulacija i analize količina materijala potrebnih za izgradnju.

Idejnim rješenjem [2, 3] predviđa se proširenje postojeće plaže na zapadnom dijelu uvale nasipavanjem prirodne obale te izgradnjom armirano-betonskih zidova prema moru. Zbog ovog će zahvata doći do povećanja koeficijenta refleksije valova u odnosu na postojeću stjenovitu obalu (Slika 1 i 2). 


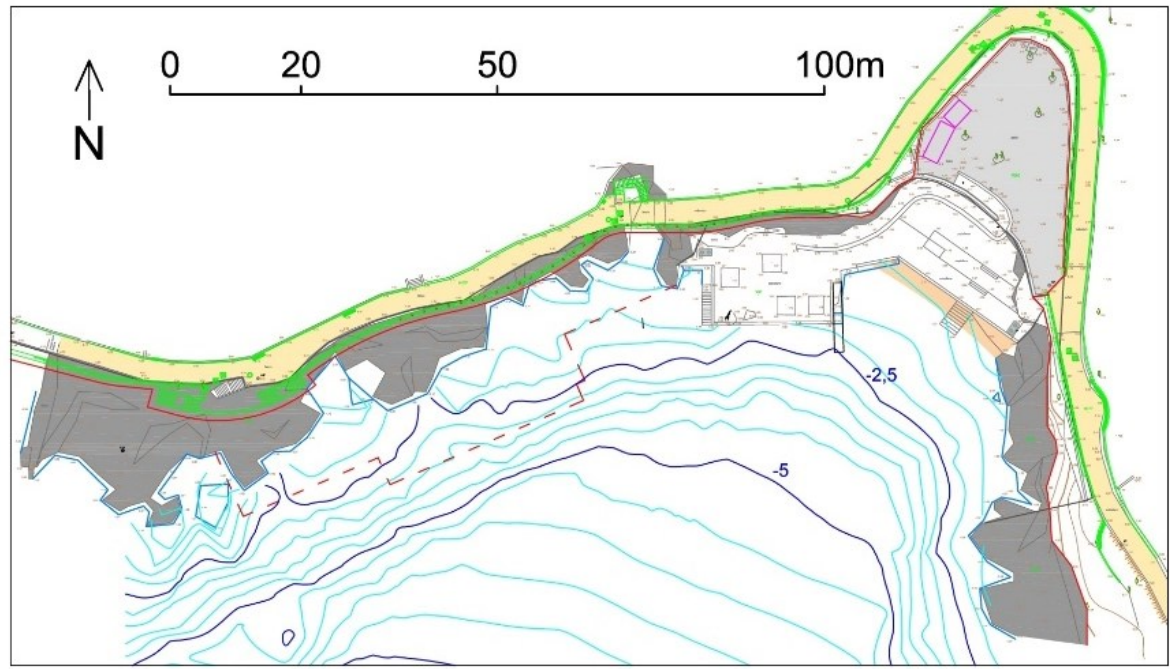

Slika 1. Postojeće stanje plaže Kostanj [2, 3]

Obalni zid je konstrukcija koja se nalazi na granici između obale i mora, a najčešće se izvodi s vertikalnim licem prema moru. U konstruktivnom smislu, obalni zidovi mogu biti gravitacioni, sastavljeni od žmurja ili na pilotima. Na obalnim zidovima može doći do značajne refleksije valova, odnosno povećanja visina valova u akvatoriju ispred samog zida. To povećanje visine valova nepovoljno utječe na stabilnost same obale, odnosno obalnih konstrukcija, a može imati nepovoljan učinak na plovidbu manjih plovila.

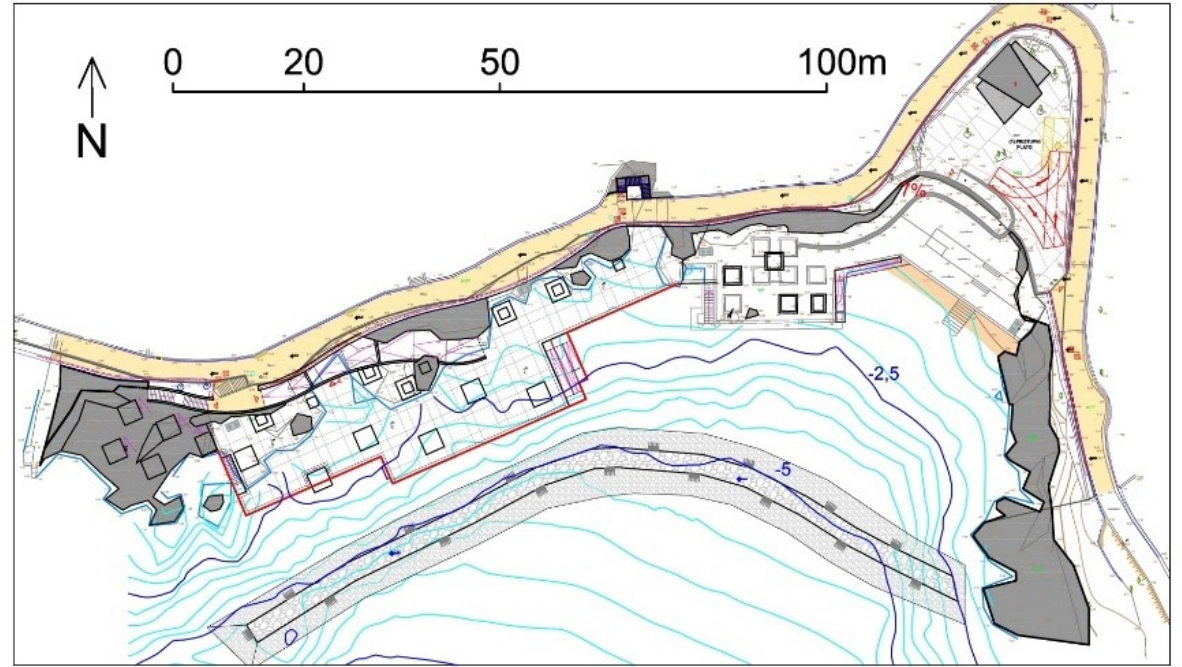

Slika 2. Projektirano stanje plaže Kostanj [2, 3] 
Podmorski prag je konstrukcija s nisko postavljenom krunom iznad ili ispod morske razine, paralelno s obalom. Njegova funkcija je disipacija valne energije, odnosno smanjenje visina nadolazećih valova a time i zaštita obale iza praga. Parametarska analiza provedena je s ciljem procjene utjecaja glavnih geometrijskih parametara na učinkovitost podmorskog praga (Slika 3).

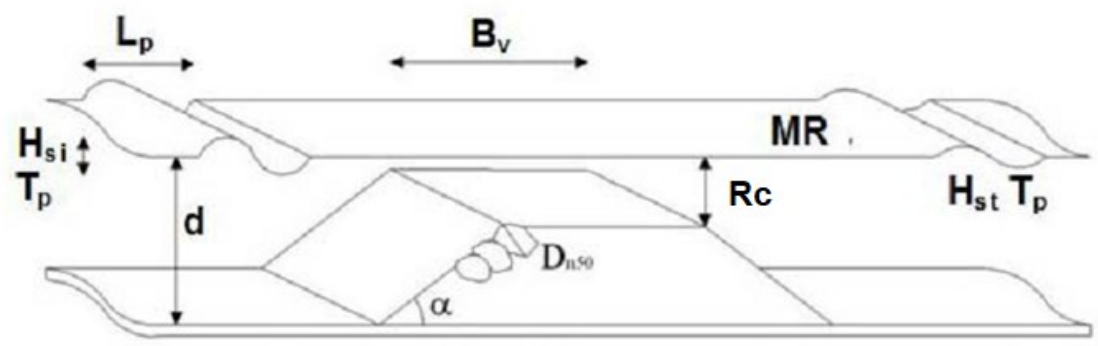

Slika 3. Shematski prikaz podmorskog praga, dubina mora (d); uronjenosti krune $(R c)$, širina praga $(B v)$, nagiba pokosa $(\alpha)$.

Efikasnost podmorskog praga procjenjuje se s obzirom na koeficijent transmisije valova $K_{\mathrm{t}}$, koji je definiran kao omjer transmitirane $H_{\text {tr }}$ i dolazne $H_{\text {si }}$ značajne visine vala:

$$
K_{t}=\frac{H_{s t}}{H_{s i}}
$$

Vrijednosti koeficijenta transmisije nalaze se u rasponu od 0 do 1 , a manje vrijednosti ukazuju na bolju efikasnost ove građevine.

\section{Metodologija istraživanja}

Numeričke simulacije valovanja provedene su u modelu SWAN za najnepovoljnije značajne visine dubokovodnih valova iz smjera SSE, i to 3,5 $\mathrm{m}$ za 50-god. povratni period, uz vršni period $T_{\mathrm{p}}=5,6 \mathrm{~s}$. Visine valova definirane su na osnovi prognoze valova sa SSE privjetrištem od $26,1 \mathrm{~km}$ te jačinom vjetra 50 -god. povratnog perioda od $26,9 \mathrm{~m} / \mathrm{s}$ [2]. Navedene visine valova zadane su kao rubni uvjeti numeričkih simulacija.

Numeričke analize provedene su na domeni analiziranog područja koja je definirana u Kartezijevom koordinatnom sustavu. Veličina prostorne domene iznosi 350 x $250 \mathrm{~m}$ uz prostorni korak $\Delta \mathrm{x}=2 \mathrm{~m}$ i $\Delta \mathrm{y}=2 \mathrm{~m}$. Digitalni model terena (DMT) izrađen je na temelju geodetskog snimka podmorja batimetrije [3].

Numeričke analize provedene su za ukupno četiri varijante. Najprije se ispitalo djelovanje valova za postojeće stanje prirodne obale, a zatim je 
ispitano djelovanje valova na konstrukciju nakon izvedenog stanja nove plaže, i to varijanta bez izvođenja zaštitnog praga (varijanta A) te uz izvođenje tri različita oblika podmorskog praga (varijante B, C i D). Razlike u obliku i položaju podmorskog praga prema varijantama A-D prikazane su tlocrtno na Slici 4 te karakterističnim poprečnim presjecima na Slici 5. Svaki podmorski prag je integriran u DMT, čime se omogućilo provođenje numeričkih simulacija na četiri različita digitalna modela terena.

Koeficijent refleksije valova za numeričke simulacije postojećeg stanja valovanja odabran je s vrijednosti $K_{\mathrm{r}}=0,40$, što predstavlja procijenjeni koeficijent refleksije stjenovite obale. Za projektirane vertikalne betonske zidove odabrana je vrijednost koeficijenta refleksije $K_{\mathrm{r}}=0,70$ zbog relativno niske kote vrha obalnog zida (+0,60 m n.m.).

Varijanta A je projektirana obala plaže Kostanj u slučaju ako se ne izvodi podmorski prag, već samo obalni zidovi projektirane plaže (Slika 4 i 5).

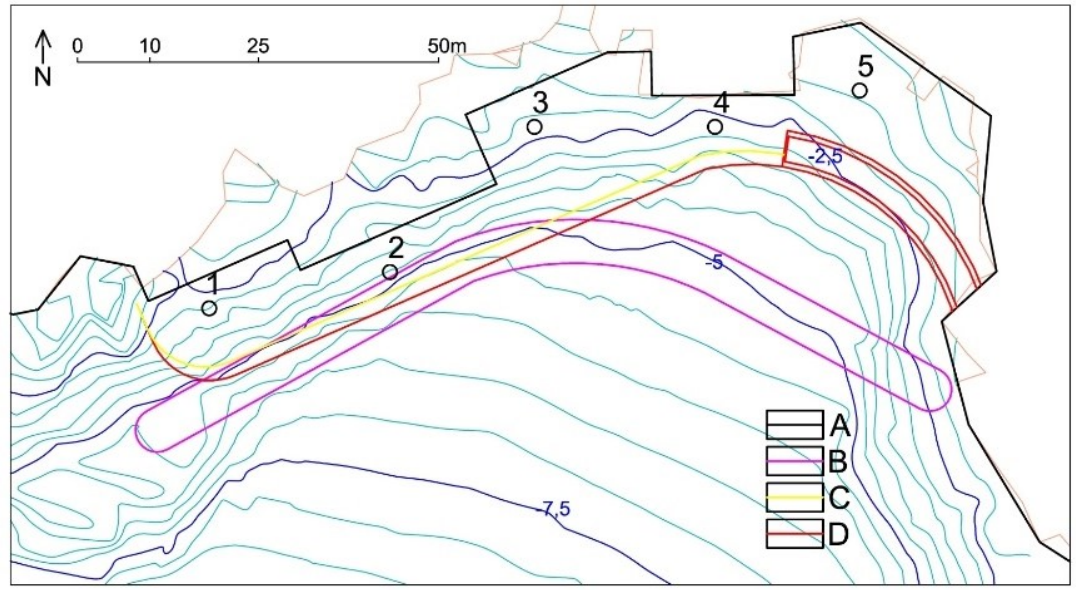

Slika 4. Prikaz analiziranih varijanti podmorskog praga: obalni zid (A), obalni zid s podmorskim pragom (B-D)

Varijanta B predstavlja simulaciju u slučaju izvođenja obalnog zida kao $\mathrm{u}$ varijanti A, s podmorskim pragom udaljenim od obalne linije oko $28 \mathrm{~m}, \mathrm{~s}$ kotom krune -2,0 m n.m. te širinom krune 6,0 m (Slike 4 i 5). Potrebno je $4100 \mathrm{~m}^{3}$ materijala za izvođenje praga ovih dimenzija. Izvedba ove varijante je složena i materijalno zahtjevna zbog najveće udaljenosti od projektirane obale, što značajno povećava troškove izvođenja.

Varijanta C simulira izvođenje obalnog zida (varijanta A), s podmorskim pragom dužine oko $100 \mathrm{~m}$, sa krunom kote $-2,0 \mathrm{~m}$ n.m. koja se proteže do projektirane obale (Slike 4 i 5). Ispred plaže kota krune praga podiže se na $-1,5$ m n.m. zbog zaštite plaže. Iako je dubina od $-1,5$ m n.m. u dometu kupača, u ovom slučaju ne bi trebala predstavljati problem jer se nalazi u 
nastavku tijela žala koje se postepeno spušta do navedene dubine. Prag bi se izvodio do dubine od $-6,5 \mathrm{~m}$ n.m. Potrebno je oko $2150 \mathrm{~m}^{3}$ materijala za njegovu izradu. Izvođenje ove varijante praga je relativno jednostavno zbog mogućnosti nasipanja $\mathrm{s}$ obale, bez potrebe angažmana specijalizirane mehanizacije za izvođenje podmorskih radova.

Varijanta D predstavlja izvođenje obalnog zida (varijanta A), s podmorskim pragom koji je 4,0 m širi u odnosu na prag varijante C. Dužina praga je oko $100 \mathrm{~m}$, s krunom na koti $-2,0 \mathrm{~m}$ n.m. koja se proteže do projektirane obale (Slike 4 i 5). Ispred plaže, kota krune praga podiže se na $-1,5$ m n.m. zbog zaštite plaže. Prag bi se izvodio do dubine od - 7,5 m n.m. Potrebno je oko $2870 \mathrm{~m}^{3}$ materijala za izvođenje praga. Izvođenje ove varijante praga je također relativno jednostavno zbog mogućnosti izvođenja s obale, bez potrebe angažiranja specijalizirane mehanizacije.

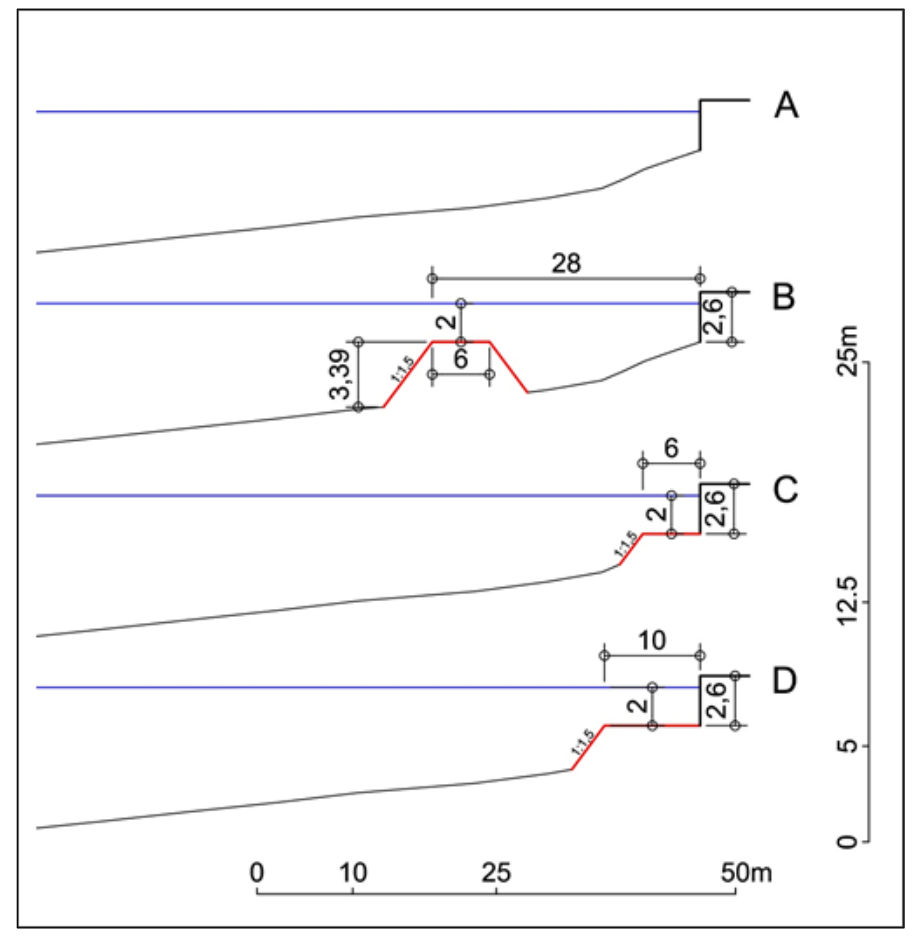

Slika 5. Prikaz presjeka u točci 2 (Slika 4) analiziranih varijanti podmorskog praga: obalni zid (A), obalni zidovi s podmorskim pragom (B-D)

\section{Rezultati}

Kako bi se prikazao utjecaj obalnog zida i odabrala optimalna varijanta podmorskog praga, uspoređene su vrijednosti simuliranih značajnih visina valova na odabranih pet kontrolnih točaka ispred postojeće i planirane 
obale plaže Kostanj (Slika 4). Odabrane kontrolne točke označene su brojevima 1 - 5, a udaljene su od projektirane obale od 5 do $8 \mathrm{~m}$. Uspoređene su značajne visine valova (Slika 6) za postojeće stanje, u slučaju izgradnje samo obalnog zida (varijanta A) te u slučaju izgradnje obalnog zida i više varijanti podmorskog praga (varijanta B - D). Odabir optimalne varijante temelji se na usporedbi efikasnosti i potrebne količine materijala, što je prikazano u Tablici 1 i na Slici 6. Simulirane značajne visine valova juga (SSE), 50-god. povratnog perioda postojećeg stanja uspoređene su $\mathrm{s}$ varijantama A-D (Slika 6, Tablica 1).

U slučaju izgradnje obalnog zida dolazi do povećanja značajnih visina valova u kontrolnim točkama do $0,20 \mathrm{~m}$ u odnosu na postojeće stanje. To nije veliko povećanje zbog niske kote projektirane obale, zbog koje je pak koeficijent refleksije obale 0,70 . No povećanje visina valova oko $10 \%$ značajno povećava opterećenja djelovanja valova na građevinu te smanjuje trajnost i funkcionalnost građevine (Slika 6, Tablica 1). Najveće simulirane značajne visine valova su u kontrolnoj točci 2 i iznose $2,85 \mathrm{~m}$, što je povećanje za 0,25 m u odnosu na valove postojećeg stanja.

Da bi se umanjili negativni učinci izgradnje obalnog zida, smanjila ukupna opterećenja na konstrukciju te povećala trajnost i funkcionalnost projektirane plaže, ispitao se utjecaj podmorskog praga. U slučaju izvođenja podmorskog praga varijante $B$, visine valova u odnosu na postojeće stanje smanjile bi se do $0,65 \mathrm{~m}$ na kontrolnim točkama. Značajne visine valova $\mathrm{u}$ kontrolnim točkama su manje od 2,0 m. U kontrolnoj točci 2 simulirana značajna visina vala je $1,95 \mathrm{~m}$, što je značajno smanjenje u odnosu na varijantu A (Slika 6, Tablica 1).

Numeričke simulacije varijante $C$, obalnog zida i praga koji se pruža do obale prikazuju smanjenje visina valova u odnosu na postojeće stanje od 0,10 do $0,50 \mathrm{~m}$. Simulirana značajna visina vala u kontrolnoj točci 2 je 2,10 $\mathrm{m}$, što je povoljnije u odnosu na varijantu $\mathrm{A}$, ali nepovoljnije u odnosu na varijantu B (Slika 6, Tablica 1).

Proširenjem praga koji se pruža do obale (varijanta D) došlo je do smanjenje simuliranih visina valova u odnosu na postojeće stanje do 0,60 $\mathrm{m}$. Simulirana značajna visina vala u kontrolnoj točci 2 je $2,00 \mathrm{~m}$, što je povoljnije u odnosu na varijante A i C, ali nešto nepovoljnije u odnosu na varijantu B (Slika 6, Tablica 1). 
Tablica 1. Prikaz rezultata numeričkih simulacija značajnih visina valova SSE, 50god. povr. per. $\left(\mathrm{Hs}^{50}\right)$ u kontrolnim točkama (Slike 4 i 6 )

\begin{tabular}{|r|l|l|l|l|l|}
\hline \multicolumn{7}{|c|}{ Značajne visine valova SSE, 50-god. $P$ P $H_{\mathrm{s}}^{50}(\mathrm{~m})$} \\
\hline Varijanta & Postojeće & Var A & Var B & Var C & Var D \\
\hline Volumen $\left(\mathrm{m}^{3}\right)$ & 0 & 0 & 4100 & 2150 & 2870 \\
\hline Točka 1 & 2,30 & 2,45 & 1,95 & 1,95 & 1,90 \\
\hline Točka 2 & 2,60 & 2,85 & 1,95 & 2,10 & 2,00 \\
\hline Točka 3 & 1,90 & 1,90 & 1,55 & 1,55 & 1,50 \\
\hline Točka 4 & 2,05 & 2,10 & 1,80 & 1,90 & 1,80 \\
\hline Točka 5 & 1,45 & 1,40 & 1,30 & 1,35 & 1,35 \\
\hline$H_{\mathrm{s}}$ max $(\mathrm{m})$ & 2,60 & 2,85 & 1,95 & 2,10 & 2,00 \\
\hline$H_{\mathrm{s}}{ }^{\text {av }}(\mathrm{m})$ & 2,06 & 2,14 & 1,71 & 1,77 & 1,71 \\
\hline$\Delta H_{\mathrm{s}}{ }^{\text {av }}(\mathrm{m})$ & & 0,08 & $-0,35$ & $-0,29$ & $-0,35$ \\
\hline & & & & \\
\hline
\end{tabular}




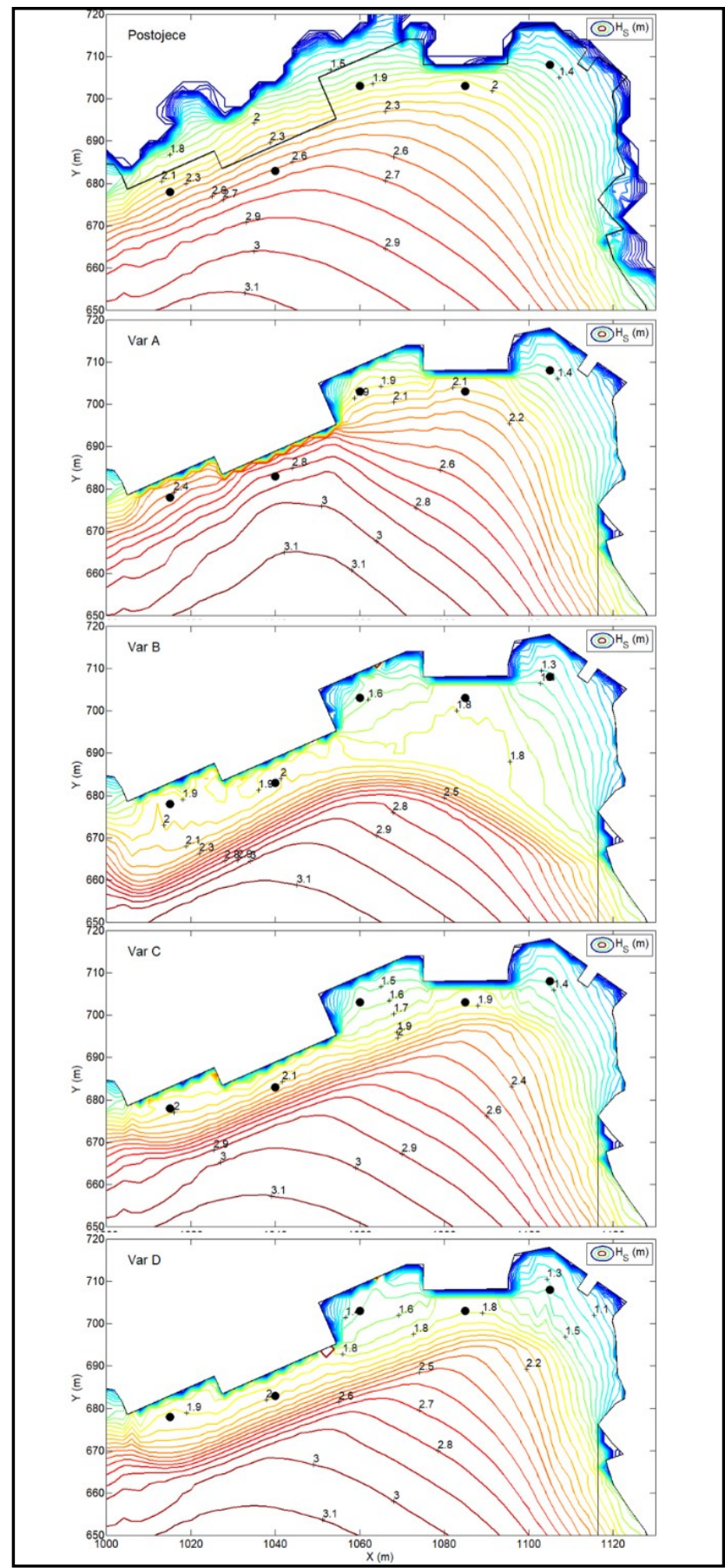

Slika 6. Prikaz rezultata numeričkih simulacija značajnih visina valova SSE, 50-god. Povratnog perioda $\mathrm{H}_{5}{ }^{\mathrm{O}}$ 
Najveće simulirane značajne visine valova su u kontrolnoj točci 2 koja je najviše izložena djelovanju dolaznih i reflektiranih valova. $U$ toj točci značajne visine valova su od 1,95 m (varijanta B) do 2,85 m (varijanta A).

Kako bi se odabrala optimalna varijanta podmorskog praga, uspoređene su vrijednosti značajnih valnih visina na odabranih pet kontrolnih točaka ispred postojeće i planirane plaže Kostanj. Odabir optimalne varijante temelji se na usporedbi efikasnosti i potrebnoj količini materijala, što je prikazano u Tablici 1. Najefikasnija geometrija podmorskog praga je Varijanta B, međutim, u slučaju izvedbe te varijante, potrebno bi bilo ugraditi znatno više materijale u odnosu na ostale varijante, što bi poskupilo izvođenje ove građevine. Varijanta $C$ zahtijeva najmanje materijala, ali ima i najslabiju učinkovitost s obzirom na umanjenje valova. Varijanta $D$ je druga po efikasnosti među analiziranim varijantama, nešto lošije efikasnosti u odnosu na varijantu $B$, ali uz utrošak manje materijala $\left(2870 \mathrm{~m}^{3}\right)$ u odnosu na Varijantu B.

\section{Diskusija utjecaja podmorskog praga na dinamička opterećenja na konstrukciju}

Pri odabiru odgovarajuće varijante podmorskog praga treba voditi računa i o procesu loma valova te opterećenjima na konstrukciju. Naime, valovi koji se lome na ili neposredno ispred konstrukcije mogu uzrokovati impulsna opterećenja nekoliko puta veća od nazovistalnih te na taj način nepovoljno utjecati na vijek trajanja obalne građevine. Prema [5], identifikacija mogućnosti pojave određenog tipa opterećenja (nazovistalna, impulsna ili opterećenja slomljenim valom) provodi se s obzirom na tip konstrukcije te dva bezdimenzionalna parametra:

$h_{\mathrm{b}}^{*}=\frac{h_{b}}{h_{s}}, \quad H_{\mathrm{s}}^{*}=\frac{H_{s i}}{h_{s}}$

gdje je $h_{b}$ dubina berme, $h_{s}$ dubina neposredno ispred berme, a $H_{s i}$ značajna visina vala neposredno ispred berme. Za rezultate dobivene ovom numeričkom analizom (za najizloženiju točku 2, SSE, 50-god. PP: $h_{b}=2 \mathrm{~m}$, $h_{b}=4,5 \mathrm{~m}, H_{s i}=2 \mathrm{~m}$ ) Jed. (2) upućuje na mogućnost impulsnih opterećenja na konstrukciju. Međutim, ovi opći izrazi ne uzimaju u obzir širinu berme ispred konstrukcije $B$. Primjerice, za kompozitne lukobrane, kod širokih bermi $\left(\frac{B}{L}>0,4\right)$, što je situacija ekvivalentna podmorskom pragu definiranim Varijantom D, očekuju se opterećenja slomljenim valovima, koji generiraju opterećenja slična nazovistalnima [5].

Lom valova i rezultirajuća opterećenja na konstrukciju su izrazito složeni hidrodinamički procesi. Pouzdana provjera hoće li lomljeni val zadržati svoju strmost sve do izloženog dijela konstrukcije, ili će se potpuno slomiti ranije i na taj način disipirati većinu svoje energije, moguća je jedino 
upotrebom složenih numeričkih modela ili eksperimentalnih analiza $\mathrm{u}$ velikom mjerilu, što nadilazi opseg ovoga rada. Pritom, u [6] dana su dva opća (empirijska) izraza za procjenu udaljenosti od obale duž koje se odvija proces loma valova, a gdje su moguća impulsna oterećenja na konstrukciju. Prvi izraz ovisi o duljini vala i glasi [6]:

$$
x_{b}=\frac{L_{b}}{2}
$$

gdje je $x_{b}$ duljina na kojoj se odvija proces loma valova, a $L_{b}=T \sqrt{g h}$ je plitkovodna duljina vala. Za $T=3,8 \mathrm{~s}$ i $h=2 \mathrm{~m}$, plitkovodna duljina vala $L_{b}$ iznosi $16,8 \mathrm{~m}$, a $x_{b}$ iznosi $8,4 \mathrm{~m}$. Drugi izraz ovisi samo o visini vala i nagibu dna, a glasi [6]:

$$
x_{b}=(4-9,25 m) H_{b}
$$

gdje je $m$ nagib dna. Za ravno dno (iznad praga) $m=0$ i $H_{b}=2 \mathrm{~m}$, duljina $x_{b}=8 \mathrm{~m}$. Dakle, može se zaključiti da će se proces loma vala odvijati duž $8-8,5 \mathrm{~m}$ te da je konstrukcija koja je udaljena $10 \mathrm{~m}$ od ruba praga izvan zone opasnosti od impulsnih opterećenja lomljenim valovima.

Kako bi se dodatno potvrdile ove provjere, na Slici 7 prilaže se i rezultat numeričkog modela SWAN na kojem je prikazana ukupna disipacija energije, gdje je primjetno kako se energija vala većim dijelom disipira u zoni udaljenoj od ruba obalne konstrukcije, odnosno na samoj granici praga.

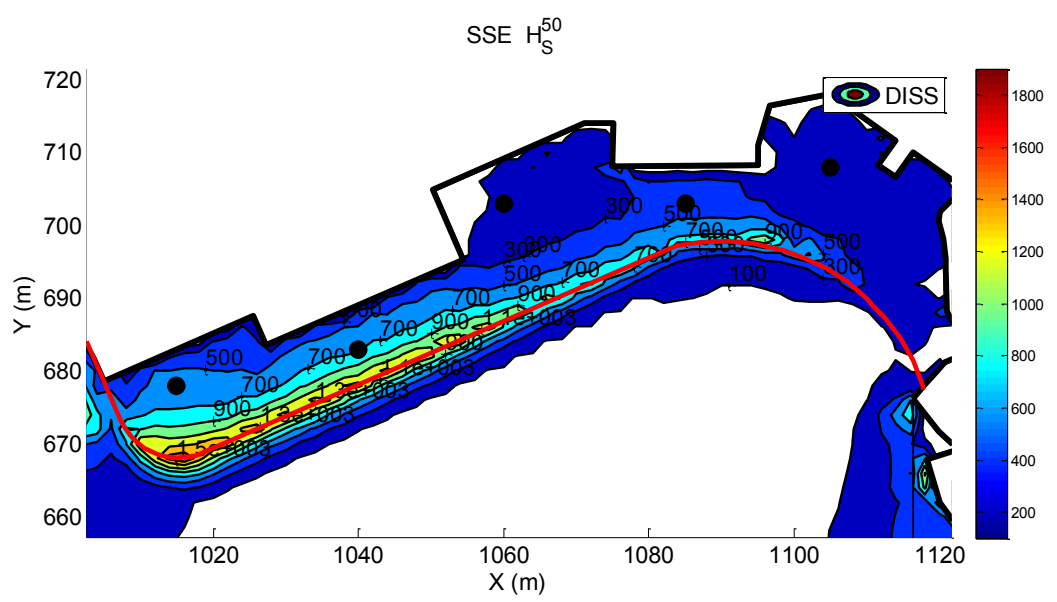

Slika 7. Prikaz rezultata numeričkih simulacija disipacije energije za valove SSE, 50god. povratnog perioda $\mathrm{HS}^{50}$

Također, pojava impulsnih opterećenja lomljenim valovima malo je vjerojatna ili minorna zbog očekivanog značajnog prelijevanja valova preko zida. Naime, vrh obalnog zida je na koti od 0,60 m n.m., a dominanta valna opterećenja su iz smjera SSE, odnosno tijekom puhanja juga koje prate i povišene morske razine. To će uzrokovati značajna prelijevanja pa i 
potapanja konstrukcije, što značajno smanjuje opterećenja uzrokovana djelovanjem valova.

\section{Zaključak}

U ovom su radu provedene matematičke analize valovanja u uvali Kostanj. Analizirano je više varijantnih rješenja izvedbe podmorskog praga s ciljem zaštite obalne konstrukcije nepovoljnog djelovanja valova. Efikasnost podmorskog praga ocijenjena je u odnosu na umanjenja nadolazećih valova. Empirijski izrazi sugeriraju kako se efikasnost podmorskog praga (koeficijent transmisije valova) povećava s visinom te širinom krune. No svako povećanje dimenzija rezultira povećanim količinama materijala koje je potrebno ugraditi te se time povećava vrijednost investicije, što s ekonomskog, odnosno inženjerskog aspekta nije prihvatljivo.

Ispitano je pet varijantnih rješenja pomoću matematičkog modela na osnovu čega je procijenjena njihova efikasnost u umanjenju valova i $u$ odnosu na potrebne količine materijala.

Izgradnjom obalnog zida (varijanta $A$ ) dolazi do povećanja značajnih visina valova ispred samog zida na najnepovoljnijoj lokaciji sa $2,60 \mathrm{~m}$ za postojeće stanje na $2,85 \mathrm{~m}$. To je značajno povećanje visina valova koje nepovoljno utječe na stabilnost, trajnost i funkcionalnost konstrukcije. Zaštita od podlokavanja obalnog zida varijante A izazvala bi dodatne značajne troškove tijekom gradnje.

Nepovoljne učinke utjecaja obalnog zida na polje valova moguće je umanjiti izgradnjom podmorskog praga (varijanta B-D). Sve ispitane varijante podmorskog praga bitno su umanjile značajne visine valova ispred obalnog zida; značajne visine valova na najnepovoljnijoj lokaciji su od $1,95 \mathrm{~m}$ do $2,10 \mathrm{~m}$ u slučaju izgradnje jedne od predloženih varijanti praga.

Kao najpovoljnija, predložena je varijanta $D$ zbog efikasnosti i potrebnih količina materijala. Izgradnjom produženog praga varijante $D$ postigla bi se i zaštita obalnog zida od podlokavanja. Varijanta D je relativno jednostavna za izvođenje zbog mogućnosti izvođenja većine radova s obale na relativno malim dubinama mora.

Problem promjena parametra valova na potopljenom lukobranu zbog refleksije i transmisije valova je veoma složen i sastoji se od većeg broja različito (ne)istraženih čimbenika i njihovoj interakciji. U ovom radu obrađen je utjecaj, odnosno promjene značajne visine vala, što predstavlja preliminarnu analizu ovog problema. Za kompletan uvid u predmetnu problematiku djelovanja valova na obalne konstrukcije iza potopljenog praga potrebno je sagledati fenomen smanjenje perioda lomljenih valova na zavjetrinskoj strani praga [7-9] te utjecaj interakcije između incidentnih valova i povišenja razine mora iza potopljenog lukobrana $[10,11]$. 


\section{Literatura}

[1] Booij, N., Ris, R.C., Holthuijsen, L.H. (1999) A Third-Generation Wave Model for Coastal Regions, Part I: Model Description and Validation. Journal of Geophysical Research, Vol. 104, C4,; 7649-7666.

[2] Građevinski fakultet u Rijeci (2018) Hidrodinamička valna analiza za odabrano tehničko rješenje rekonstrukcije i proširenja plaže Kostanj u Rijeci.

[3] Arhitektonsko-građevinski atelje, Rijeka (2017) Rekonstrukcija i proširenje plaže Kostanj, Idejni projekt - projekt arhitekture.

[4] Pilarczyk, K.W., (2003) Design of Low-Crested (Submerged) Structures-an Overview, 6th International Conference on Coastal and Port Engineering in Developing Countries, Colombo, Sri Lanka.

[5] US Army Corps of Engineers (2002). Coastal Engineer Manual 1110-2-1100. US Army Corps of Engineers, Washington, DC (in 6 volumes). US.

[6] Coastal Engineering Research Center (1973) Shore Protection Manual (Vol. 1). Corps of Engineers. US.

[7] Goda, Y., Suzuki, Y., Kishira, Y., (1974) Some Experiences in Laboratory Experiments with Irregular Waves. Proc. 21st J. Conf. Coastal Engrg, pp. 237242.

[8] Raichlen, F., Cox, J.C., Ramsden, J.D., (1992) Inner Harbor Wave Conditions due to Breakwater Overtopping. Proc. Asce, Coastal Engineering Practice, Long Beach, California, USA.

[9] Carevic, D., Loncar, G., Prsic, M., (2013) Wave Parameters after Smooth Submerged Breakwater. Coastal Engineering, 79, 32-41.

[10] Petti, M. and Ruol, P. (1991) Experimental Study on the Behaviour of Submerged Detached Breakwaters, 3rd International Conference on Coastal and Port Engineering in Developing Countries, Vol. 1, , pp. 167 - 179.

[11] Liberatore, G. and Petti, M. (1993) Wave Transformations Over a Submerged Bar: Experiments and Theoretical Interpretations, 23" International Conference on Coastal Engineering, ASCE , New York, Vol. 1,. pp. 447-459. 